\title{
Sustainable Consumption from the Perspective of Environmental Ethics
}

\author{
Shao-hua Zhou ${ }^{1,2,3}$, Ping Fang ${ }^{1,2,3 *}$ \\ ${ }^{1}$ Collage of Environmental Science and Engineering, Tongji University \\ ${ }^{2}$ UNEP-Tongji Institute of Environment for Sustainable Development \\ ${ }^{3}$ Key Laboratory of Cities' Mitigation and Adaptation to Climate Change, Shanghai, China Meteorological Administration \\ (CMA), Tongji University, Shanghai, 200092, P. R. China \\ * Corresponding author: fangping2000@ tongji.edu.cn
}

\begin{abstract}
Consumption is extremely important for our society and it is the foundation of human existence and development. It is not only an economic issue but also an important ethical issue. Nowadays there are some unhealthy phenomenon occurs in the consumption areas. Food waste, a prominent issue, is harmful for the society, resources, the environment and also people's health. It is contrary to the resource-saving and environment-friendly society. This paper focuses on food waste, and puts forward the concept of sustainable consumption. Practicing sustainable consumption in daily life can help to alleviate the severity of environmental problems, improve public health, and ensure the environment to have a sustainable development.
\end{abstract}

Index Terms - sustainable consumption, food waste, environment, environmental ethics

\section{Background}

Since the reform and opening up, Chinese economic development has made significant achievements, and people's living standards have been greatly improved. But at the same time there are some unhealthy phenomenon occurs in the consumption areas, and it also brings many environmental issues [1]. The environmental change directly affects the quality of our life. Uncontrolled consumption accelerates the pace of environmental degradation. At present, Chinese unscientific food consumption patterns are causing large numbers of resources waste and environmental pollutions, which threat the harmonious development of material civilization and spiritual civilization, and restrict the sustainable food production and sustainable consumption processes [2].

The appearance of sustainable consumption implies the development of social culture and civilization [3]. Sustainable consumption advocates the combination of consumption with the nature. Developing sustainable consumption and people can have scientific, rational consumption awareness and form a civilized and healthy consumption pattern. It is beneficial for sustainable socio-economic development, but also beneficial to cultivate good moral character and lofty spiritual realm, to achieve mutual symbiosis between human and the nature.

\section{The Related Theory of Environmental Ethics}

Environmental ethics is used to regulate the ethical relationship among human beings or between human and the nature, establish codes of ethics and codes of conduct, which can handle the relationship correctly.

The norms of environmental ethics are as below:

\section{A. Environmental Protection}

In environmental ethics, environmental protection is to protect all lives on earth, preserve the integrity of ecosystem, use and develop natural resources rationally, protect the environment from destruction and pollution. Protecting environment has become a code of ethics that people all over the world should follow.

\section{B. Respect the Nature}

Human and the nature are a complete community, and people can't lead the nature, also can't ignore the nature. The nature is the source of life and value of human beings. But like human's life, natural resources are also limited. We must learn to respect nature, changing our attitudes to the nature fundamentally and treating natural development and utilization from an ethical perspective.

\section{Reverence for Life}

When human beings handle the relationship with other living things, they always stand for the interests of themselves. From the point of environmental ethics, human is also a member of the community, we should handle the relationship between human and other living things properly. So the moral demand of reverence for life is raised to regulate the relationship between man and biological interest.

\section{Rational Consumption}

Nowadays, environmental problems we face are closely related to our consumption patterns. Rational consumption focuses on spiritual consumption and opposes to uncontrolled consumption. It advocates people to practice sustainable consumption. Rational consumption is not just a necessary requirement for healthy and sustainable development of the economy, but also an important requirement for environmental ethics. 


\section{The Current Situation of Food Waste in China}

At present, the main food waste is the shocked waste on the table in China. With rising living standards, more and more people eat outside. Coupled with increased mobile population, food market is booming and has great potential. National Bureau of Statistics' data shows that the accumulated income was 2,539.2 billion Yuan of all national restaurants, accounting for $4.5 \%$ of GDP and an increase of 9\% in 2013. The survey data of Agricultural Information Institute of Chinese Academy of Agricultural Sciences shows that protein in catering waste food can reach 8 million $\mathrm{t}$ per year, fat can reach 6.3 million $\mathrm{t}$, and a conservative estimate of grain waste per year can reach 2.2 million t. More than 20 million t table food is drained up in the provincial cities or above [4]. Articles and pictures of food waste frequently appears in major media, and the most serious is the food waste in weddings. The waste in the canteens of major universities is also extremely alarming and only one university canteen would throw five or six hundred pounds leftovers at noon per day [5].

Food waste will bring great harm to society, resources, environment and people's health. It reflects not only the level of economic development of a Country, but also the degree of life civilization in this Country. Reducing food waste is not only a personal matter; it is also a big issue related to the food resources of 1.3 billion populations.

\section{The Reasons of Food Waste}

There are so many causes of food waste, and we can generalize it into four aspects.

A. Effective Mechanism to Restrict Waste hasn't been Formed

Saving food resources is the proper behavior for every person, and an important goal of social maturity of modern management. Currently, food waste is closely related with the four major social problems of resources, environment, energy and health. Waste limited requires the support of a range of social restraint mechanisms and conditions, but our Country is lack of.

\section{B. Public Awareness of Food Resources Conservation is not Strong}

Taking the habit of guest reception or weddings as an example, food consumption mostly takes rich and surplus as the target and there is no sense to reduce waste. Especially after we improved the material conditions of life, the atmosphere of pursuit of luxury and ceremony is easy to pop. The conservation awareness is weaker and weaker.

\section{The Environmental Conditions during Consumption are Inadequate}

For example, standards of food production, processing, catering or processing of agricultural raw material standard are not perfect, so processors can't allocate raw materials in accordance with various processing needs, which results in waste.

\section{The Technology Level Used after Food Production is not very High}

About 80 percent of our food processing technologies and equipments is only equivalent to the world average in the 1970s and 1980s; $15 \%$ reaches the level in the 1990s, and only $5 \%$ reaches the international advanced level. Technology levels of harvest, transport, storage and processing are not high, resulting in a huge waste of food.

\section{The Related Theory of Sustainable Consumption}

Sustainable consumption, a new consumer attitude and consumption pattern, is produced to re-examine the relationship between human and the nature. It abandons traditional evaluation criteria for environmental values, and reconstructs a new one: non-anthropocentrism. It is significant for alleviating the severity of environmental problems, improving public health, and changing social lifestyle.

\section{Sustainable Consumption Paths Under the Practice of Environmental Ethics}

\section{A. Strengthen the Publicity and Education of Sustainable Consumption}

From receive to identity and to practice is a long and arduous process for consumers. The task at this stage is to propagandize sustainable consumption ideas and ways vigorously to make it popularity. We can rely on magazines, newspapers, television, Internet and other media. Develop community sensitization activities or grant sustainable consumption brochures to disseminate the knowledge of sustainable consumption, or raise people's awareness through education channels.

\section{B. Formulate and Practice Sustainable Consumption Norms that Conforms with Environmental Ethics}

Formulate the sustainable consumption behavior norms of "5R". Sustainable consumption requires people consider not only whether it is beneficial to the healthy development of their living environment, but also whether it is helpful for environmental protection and ecological balance when they are consuming. In order to save the earth and protect the human beings' living environment, we must practice sustainable consumption from our daily life.

\section{Strengthen the Participation of Government}

In order to promote the popularization and development of sustainable consumption, except in accordance with markets, we should also strengthen the participation of government. Increasing the green investment, the establishment of specialized sustainable consumption regulatory, building sustainable marketing system or other methods all can strengthen the promotion of sustainable consumption.

\section{Improve the Legal Construction of Sustainable Consumption}

Now, China is still lack of a specialized and completed sustainable consumption laws and regulations. As ecological damage is increasingly serious, it is necessary to take the form 
of legislation. We should define sustainable consumption as the legal obligations of consumers, so that it can better achieve environmental protection and resource conservation, the requirements of sustainable development.

\section{Conclusions}

In recent years, economy has had a rapid development in our Country, but at the same time, it also causes very serious environmental pollution. And negative impact caused by human beings' irrational consumption has become increasingly evident. We have suffered the food waste, environmental pollution and other environmental issues. Faced with the current status of unsustainable development, practicing sustainable consumption and solving the problems existing in sustainable consumption under the perspective of environmental ethics has become the urgent needs for our Country.

\section{References}

[1] CHENG Shengkui, GAO Liwei, etc. Food Waste in Catering Industry and Its Impacts on Resources and Environment in China, Technology and society, 2012, 7.

[2] GAO Liwei, CHENG Shengkui, CAO Xiaochang, ZHANG Dan, LIU Xiaojie etc. An overview of the resources and environmental issues from wasted food in urban catering across China, Journal of Resources and Ecology, 2013, 12(4).

[3] QIN Shusheng, WANG Kuan. Green Consumption and Ecological Civilization Construction, Academic Exchange, 2013, 5.

[4] WANG Yu. Causes and Countermeasures of Food Waste in China, Agricultural Outlook, 2014,6.

[5] XIA Han, ZHANG Liwen. Let Green Consumption Come into Campus, Environmental Management in China , 2008, 6. 